UDC 336.71:[007:004.738.5]:339.138-043.86

JEL Classification G21; M15; M31

\author{
Mariana Demko \\ Postgraduate Student of the Department of Marketing \\ Faculty of Economics, Ivan Franko National University of Lviv
}

(Lviv, Ukraine)

\title{
DEVELOPMENT OF INTEGRATED MARKETING INTERNET COMMUNICATIONS IN THE ACTIVITY OF UKRAINIAN BANKS
}

In modern conditions the Internet is developing rapidly. Marketing communications on the Internet is one of the main elements of Internet marketing of banking institutions and an important element in establishing relationships with target audiences and managing them, informing customers, improving the image of the bank. It is determined that the Internet today covers the information, communication and logistics areas of marketing communications of banks. The paper identifies the areas of integrated marketing Internet-communications in the activities of banks and their main elements to present their characteristic. At the present stage of development of Internet-communications in activities banking, it is advisable for banking institutions to use advertising, digital and creative strategies. It was found that the current trends in the development of marketing communications on the Internet also indicate the growth of Internet-communications in social networks as an important mechanism for interesting the bank customers and forming interaction with them and the development by the bank of its website, its attractive design, updating information on it. The results of the study showed that the largest share of Internet users in Ukraine uses mobile phones or smartphones, the number of which is growing, which expands the capabilities of banks in the field of Internetcommunications. It was established that the most active banks in the media space are banks with state share: JSC CB «PrivatBank», JSC «Oschadbank», JSC «Ukreximbank» and banks of foreign banking groups such as JSC «Raiffeisen Bank Aval», JSC «OTP BANK», JSC «ALFA-BANK». JSC «FUIB» is among the banks with private capital. At the same time, the largest media activity of banks in 2019 was observed in banks of foreign banking groups, and in 2019, 2021 by the number of messages in stateowned banks. The analysis of the collected marketing information showed that the largest number of messages from the leading banks of Ukraine by categories of media was observed in the Internet media, as the Internet is a convenient, cheap and effective communication channel in all areas activities. The expediency of using the Internet to promote banking products is also due to the fact that recently the effectiveness of traditional channels for disseminating information about banks and their products has decreased.

Key words: integrated Internet-marketing communications, banks, Internet marketing, mediaactivity of banks, means of information dissemination.

DOI: 10.15276/mdt.5.1.2021.6

Problem statement in general and its connection with important scientific or practical tasks. Modern conditions actualize for banking institutions the use of Internet marketing as an effective tool for marketing activities. Through the Internet, it is possible to implement marketing measures faster, explore the market situation, adapt communication

(C) 2021 The Authors. This is an open access article under the CC BY license (http://creativecommons.org/licenses/by/4.0)

M. Demko. Development of integrated marketing Internet communications in the activity 
policies in accordance with market conditions, to ensure the acceptance of consumer orders. In the information society, economic results depend on the effective management of the system as a whole. Informatization involves the widespread and effective implementation and application of information and communication technologies and innovations in banking.

Analysis of the latest research and publications, which initiated the solution of this problem. Trends in the development of Internet marketing, marketing Internetcommunications were studied by such scientists as K.Malinoshevskaya [1]; A.Kulyk [2]; T.Dubovik, V.Ortynska [3]; N.Kosar, Yu.Pankivska, N.Kuzio [4]; N.Duchynska, K.Gulyaeva [5]; P.Bradulov [6]; L.Zatsna [7]; A.Kuzmenko, Yu.Tretyak [8] and other. Scientists have viewed Internet marketing as a promising tool that will replace traditional mass media and will also apply to solve a wide range of marketing tasks. Along with that, scientists pay great importance to integrated Internet marketing communications as to an important element of managing relationships with target audienceses.

In particular, K.Malinoshevskaya notes that the Internet, including Internet marketing, will gradually replace traditional mass media. Over time, the global information network will be an important tool for implementing integrated marketing communications, as well as marketing programs. Subjects of the advertising market are primarily interested in the development and application of Internet marketing, ,i.e. advertisers, media, advertising agencies for conducting communication activities, as well as customers in obtaining and applying marketing information [1, p. 79].

A.Kulyk also notes that the Internet has new opportunities in the field of marketing, as it can be actively applied to solve a wide range of marketing tasks, including: market research, promotion, application of the Internet as a sales channel. Global computer networks form a new environment of information interaction, including the emergence of new forms of communication [2, p. 89].

T.Dubovik, V.Ortynska substantiate that the concept of «integrated Internet-marketing communications, the meaning of which is explained by their dominance in modern conditions among other electronic means of communication on the Internet, is proposed to consider as process of managing relationships with target audiences, what asserts an interactive, system approach to integrating Internet marketing communications taking into account monotype, interactivity, multidimensionality, cross-functional personalized interaction and encouragement of profitable relations of subjects of internet marketing communication of the totality in the short-, medium-, long-term perspectives with application of complex of additive measures» [3, p. 63].

N.Kosar, Yu.Pankivska, N.Kuzio, [4, p. 282] determine directions of influence of information technology, above all the Internet, on various areas of the enterprise.

Highlighting previously unsolved parts of the general problem to which the article is devoted. However, the application of modern marketing tools and innovations on the Internet in the banking sphere, which are spreading rapidly is still do not sufficiently explored in scientific publications.

Formulation of the purpose of the article (problem statement). Investigate the marketing Internet-communications of banks, analyze the media activity of Ukrainian banks, in particular, by category of media and in time.

Presentation of the main material of the study with a full justification of the obtained scientific results. The application of marketing Internet-communications involves maintaining the relationship between customers and the bank via chain the Internet. Today, the Internet covers the information, communication and logistics areas of marketing communications of banks (Table 1). 
Table 1 - Internet marketing technologies in various areas of marketing communications of banks

\begin{tabular}{|l|l|}
\hline \multicolumn{1}{|c|}{ Areas } & \multicolumn{1}{c|}{ Value } \\
\hline Information & $\begin{array}{l}\text { Receiving information, electronic surveys, sending messages, } \\
\text { monitoring the by to visitors to the bank's website }\end{array}$ \\
\hline Communication & $\begin{array}{l}\text { Organization of PR and teleconferences, advertising, brand } \\
\text { promotion, providing feedback customer }\end{array}$ \\
\hline logistics & Promotion of banking products via the Internet, on the bank's website \\
\hline
\end{tabular}

Source: built by the author on the basis of [5, p.73].

The communication space of the Internet differs from other means of disseminating information, outweighing them by a number of important characteristics [6]:

-multifunctional model of message transmission in order to implement a wide diapason of species of interactive communication interaction;

-monitoring above search for information with by customers to form an active position in the communication process;

-a wide range of types of information presentation and interactive communication interaction;

-high flexibility and scale;

-search for information due to the hypermedia nature of its presentation;

-implementation of interactive transactions: concluding agreements and making payments electronically through an electronic resource.

Integrated of marketing Internet-communications help to enhance the reputation and image of the bank. The components of marketing communications of banks on the Internet are given in table 2 .

Table 2 - Marketing communications of banks on the Internet

\begin{tabular}{|c|l|}
\hline $\begin{array}{c}\text { Marketing } \\
\text { communications }\end{array}$ & \multicolumn{1}{c|}{ Value of marketing communications on the Internet } \\
\hline $\begin{array}{c}\text { Bank advertising } \\
\text { (image, product) }\end{array}$ & $\begin{array}{l}\text { Advertising on the Internet represents a notification and informing customers } \\
\text { about the bank, banking products, provides an opportunity to interest and attract } \\
\text { new customers. Types of Internet advertising are search, media, video } \\
\text { advertising (digital) }\end{array}$ \\
\hline $\begin{array}{c}\text { PR-activities } \\
\text { (including, } \\
\text { sponsorship) }\end{array}$ & $\begin{array}{l}\text { PR activities on the Internet are aimed at improving the image of the bank, } \\
\text { attractive to the customer, interaction with social services. Sponsorship as a type } \\
\text { of Internet-communication is used when the site is sponsored by a brand }\end{array}$ \\
\hline Sales promotion & $\begin{array}{l}\text { The Internet allows to disseminate information about discounts when using } \\
\text { banking products, loyalty programs, provides the opportunity to use the system } \\
\text { «client-bank», Internet banking, mobile banking on preferential terms }\end{array}$ \\
\hline $\begin{array}{c}\text { Personal sales, } \\
\text { direct marketing }\end{array}$ & $\begin{array}{l}\text { Electronic of postal of mailings, affiliate programs. } \\
\text { Direct Internet marketing, which is based on personal direct communication with } \\
\text { the recipient of the message without information intermediaries, uses direct } \\
\text { address mailing of messages in the Internet on target consumers by using via e- } \\
\text { mail and RSS (description of news feeds, article announcements, changes in } \\
\text { blogs, etc.). Anticipates the application of search engines SEO, SMO } \\
\text { (optimization for social networks), social networks SMM (social media- } \\
\text { marketing), SEM (search marketing). }\end{array}$ \\
\hline
\end{tabular}

Source: built by the author on the basis of [7, p. 214-221; 8, p. 390] 
At the present stage of development of Internet communications in banking activity, the following may apply Internet marketing strategies can be used [9]:

-advertising strategy online advertising: the latest banking products; news from banking experts; sorting various messages for users, audience segmentation; setting up tracking of orders, sales, calls, downloading advertisements on the Internet, social networks; automation of advertising on Google and Facebook for marketers, mailings via Viber are more effective in comparison with SMS messages; messages via Instagram (but here, when there are a large number of messages, the information is not grouped, it is difficult to follow the status).

-digital strategy: information about the target audience, budget, benefits of banking products, development of IT infrastructure, quality of work CRM and databases, of site;

-creative strategy: development of corporate style of the bank, creative ideas, brand promotion.

The main advantages of banks' application of Internet marketing communications are [10, p. 112-113]:

- globalization asinformation from the Internet can be viewed anywhere in the world;

-increasing the level of information support of the activities bank as there is an opportunity at any time to conduct various marketing research, to obtain information about competitors;

- convenience for customers isthe ability to use certain services at any time 24/7 without leaving home, office;

-rapid adaptation to today's conditions is the ability to quickly respond to customer needs and proposals of competitors;

-reduction of bank costs;

- promotion of banking services, of brand.

Current trends in the development of marketing communications on the Internet, provide for the growth of Internet communications in social networks as an important mechanism for customer interest. In social networks, banks have the opportunity to:

- advertise the latest banking products; interest;

-to provide the level of information support to the client to increase his purchasing

- monitor clients;

- conduct staff training;

-visit webinars (online conferences, seminars, business meetings, staff meetings, negotiations with clients);

-organize new promotional events;

-increase customer trust by offering loyalty programs;

- to ensure the positioning of the brand, the formation of its positive image and reputation; - provide feedback;

-reduce advertising costs, etc.

O.Kots, L.Bondarenko highlight the following advantages of social networks for Ukrainian banks [11, p. 317-318]:

-informing existing and potential customers about the latest banking products;

-formation of an attractive brand of the bank and improvement of its image;

-attracting new customers through promotions, affiliate programs and loyalty programs;

-free and dynamic advertising space;

-a large audience for carrying out marketing research and testing of new banking products;

-formation of trusting communication between clients and the bank;

-the ability to adapt and respond quickly and neutralize the risk of negative information; 
-additional customer service support;

-dissemination of information about the bank (through likes, dissemination, customer comments);

-implementation of banking transactions through social networks;

-lead generation meaning the transformation of an active audience into real customers of the bank.

M.Veselova notes that social networks have become a platform for many financial topics for society, which provide an opportunity [12, p. 218]:

-increase the level of financial literacy of customers;

-increase the level of transparency of the banking system.

However, N.Kosar, N.Kuzio [13, p. 147], emphasize that to attract customers, commercial banks must also improve marketing communications within branches, at points of sale of his products with the possibility of application of the commercial bank Digital Signage or digital merchandising as a modern powerful tool to promote of his products. This tool is a component:

- of marketing communications of the bank;

- of merchandising;

- of logistics at the point of sale and service.

As note, T.Girchenko, R.Kossmann, no less important element of communication policy is the Web-site of the bank on the Internet, because it [14, p. 79]:

- provides the bank with a wide range of additional opportunities, the bank can provide users with additional services;

-the client has access to a significant amount of information, and he will form a more complete opinion about the bank and its proposals.

Therefore, banking institutions should pay considerable attention to the issues of its attractive design, updating information on it.

Today the number of Internet users in Ukraine is growing. The audience of Internet users is presented in Figure 1.

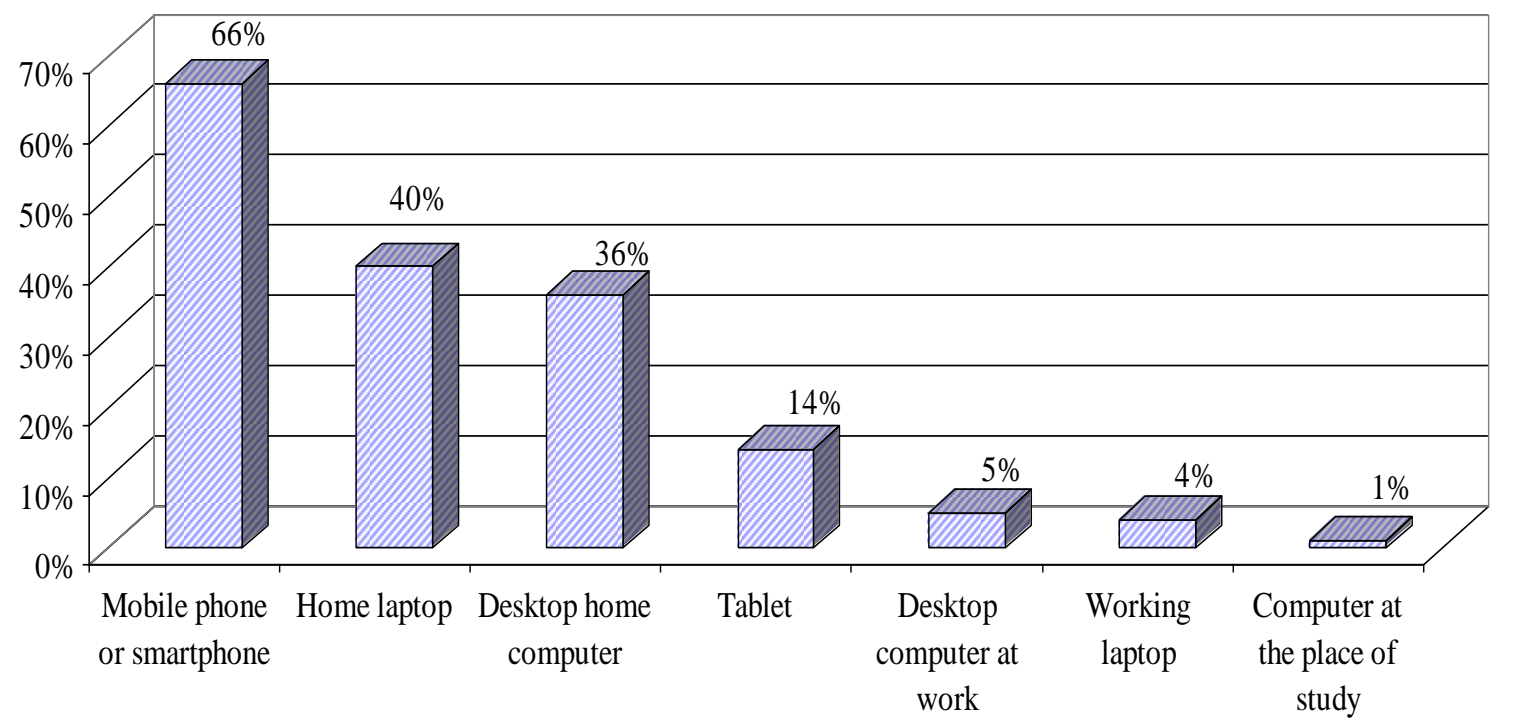

Figure 1 - Types of access of «regular» Internet users III quarter of 2019 [15]

According to research conducted in the third quarter of 2019 by the Internet Association of Ukraine (Figure 1), the largest share of Internet-users applies mobile phones or smartphones.

M. Demko. Development of integrated marketing Internet communications in the activity $\quad 105$ of Ukrainian banks 
According to the main indicators of the Internet: the share of regular users is $71 \%$, with the availability of the Internet at home $65 \%$. Among «regular» Internet users: the share of mobile device users is $69 \%$ (smartphone and tablet) and $22 \%$ of users who use only mobile devices [15].

In January 2020, the number of Internet users increased to 4.54 billion, which is $7 \%$ more (298 million new users) compared to January 2019 [16].

For the banking sector, customer trust is important. This is determined by the specifics of the bank's activities in relation to the use of funds received from customers for the purpose of profit. The basis of trust is a strong positive reputation of the bank. Carrying out media analysis allows to assess the competitive environment of the bank, to establish direct and hidden information dangers, as well as to determine the effectiveness of communications [17, p. 42]. Information on mediaactivity of Ukrainian banks is presented in table 3.

Table 3 - Mediaactivity of Ukrainian banks

\begin{tabular}{|c|c|c|}
\hline \multirow[b]{2}{*}{ Banks } & \multicolumn{2}{|c|}{ Number of messages } \\
\hline & $\begin{array}{l}25.05 .2019- \\
24.06 .2019\end{array}$ & $\begin{array}{c}08.01 .2021- \\
06.02 .2021\end{array}$ \\
\hline \multicolumn{3}{|c|}{ 1. Banks with a state share } \\
\hline JSC CB «PrivatBank» & 18171 & 12626 \\
\hline JSC «Oschadbank» & 3786 & 4833 \\
\hline JSB «UKRGASBANK» & 1439 & - \\
\hline JSC «Ukreximbank» & 736 & 1245 \\
\hline JSC «SETTLEMENT CENTER» & 17 & 11 \\
\hline \multicolumn{3}{|c|}{ 2. Banks of foreign banking groups } \\
\hline JSC «Raiffeisen Bank Aval» & 1259 & 1339 \\
\hline JSC «OTP BANK» & 1169 & 901 \\
\hline PSC «Prominvestbank» & 671 & 593 \\
\hline JSC «ALFA-BANK» & 653 & 805 \\
\hline JSC «UKRSIBBANK» & 425 & 489 \\
\hline JSC «KREDOBANK» & 368 & 481 \\
\hline JSC «PRAVEX BANK» & 316 & 203 \\
\hline JSC «CREDIT AGRICOLE BANK» & 272 & 409 \\
\hline JSC «PIRAEUS BANK ICB» & 210 & 143 \\
\hline JSC «Idea Bank» & 181 & 293 \\
\hline JSC «BANK FORWARD» & 122 & - \\
\hline JSC «BTA BANK» & 117 & - \\
\hline JSC «ProCredit Bank»» & 111 & 180 \\
\hline JSC «DEUTSCHE BANK DBU» & 101 & - \\
\hline JSC «CREDIT EUROPE BANK» & 100 & 21 \\
\hline JSC «CITIBANK» & 83 & 243 \\
\hline JSC «ING Bank Ukraine» & 24 & 32 \\
\hline \multicolumn{3}{|c|}{ 3. Banks with private capital } \\
\hline JSC «FUIB» & 456 & 970 \\
\hline JSC «BANK CREDIT DNEPR» & 299 & 199 \\
\hline JSC «TASCOMBANK» & 246 & 615 \\
\hline Pivdennyi Bank & 240 & - \\
\hline JSC «INTERNATIONAL INVESTMENT BANK» & 154 & 181 \\
\hline JSC «MEGABANK» & 143 & 278 \\
\hline PJSC «BANK VOSTOK» & 92 & 325 \\
\hline JSC «BANK FOR INVESTMENTS AND SAVINGS» & 86 & 29 \\
\hline JSC «CRYSTALBANK» & 84 & - \\
\hline
\end{tabular}


Continue table 3

\begin{tabular}{|l|c|c|}
\hline JSC «Ukrainian Bank for reconstruction and development» & 12 & 68 \\
\hline JSB «CLEARING HOUSE» & 11 & 44 \\
\hline
\end{tabular}

Source: compiled by the author according to the data $[18,19]$.

According to table 3, the following most active banks in the media space are observed:

-banks with state share: JSC CB «PrivatBank», JSC «Oschadbank», JSC «Ukreximbank»;

-banks of foreign banking groups: JSC «Raiffeisen Bank Aval», JSC «OTP BANK», JSC «ALFA-BANK»;

-banks with private capital: JSC «FUIB».

The largest media activity of banks in 2019 was observed in banks of foreign banking groups, and in 2019, 2021 by the number of messages is dominated by banks with a state share. Media activity of the largest most leading banks of Ukraine by categories of means of disseminating information in table 4.

Table 4 - Media activity of the largest most leading banks of Ukraine by categories of means of disseminating information

\begin{tabular}{|c|c|c|c|c|c|c|c|c|c|c|}
\hline \multirow[b]{2}{*}{ Banks } & \multicolumn{10}{|c|}{$\begin{array}{c}\text { Number of messages } \\
08.01 .2021-06.02 .2021\end{array}$} \\
\hline & 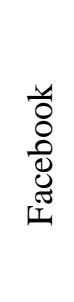 & 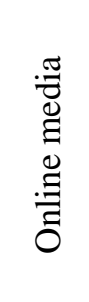 & 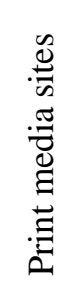 & 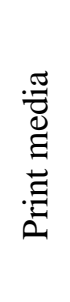 & $\begin{array}{l}0 \\
: \frac{0}{0} \\
\frac{0}{0} \\
e\end{array}$ & 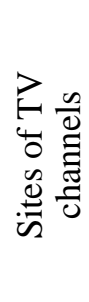 & 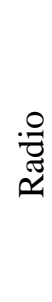 & 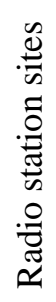 & 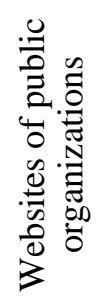 & 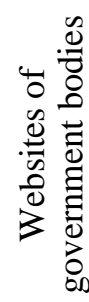 \\
\hline \multicolumn{11}{|c|}{ 1. Banks with a state share } \\
\hline JSC CB «PrivatBank» & 938 & 4682 & 258 & 73 & 79 & 276 & 3 & 13 & 70 & 203 \\
\hline JSC «Oschadbank» & 218 & 2209 & 153 & 71 & 18 & 86 & 0 & 6 & 31 & 227 \\
\hline JSC «Ukreximbank» & 40 & 674 & 45 & 12 & 7 & 19 & 0 & 2 & 10 & 46 \\
\hline \multicolumn{11}{|c|}{ 2. Banks of foreign banking groups } \\
\hline JSC «Raiffeisen Bank Aval» & 29 & 679 & 63 & 16 & 5 & 22 & 0 & 6 & 6 & 42 \\
\hline JSC «OTP BANK» & 39 & 562 & 21 & 4 & 0 & 1 & 0 & 0 & 5 & 30 \\
\hline JSC «ALFA-BANK» & 29 & 427 & 34 & 3 & 0 & 10 & 0 & 0 & 6 & 21 \\
\hline JSC «UKRSIBBANK» & 20 & 211 & 14 & 6 & 2 & 4 & 0 & 0 & 6 & 3 \\
\hline JSC «KREDOBANK» & 27 & 233 & 17 & 5 & 0 & 2 & 0 & 0 & 5 & 42 \\
\hline $\begin{array}{l}\text { JSC «CREDIT AGRICOLE } \\
\text { BANK» }\end{array}$ & 16 & 212 & 10 & 1 & 0 & 2 & 0 & 0 & 1 & 3 \\
\hline JSC «PRAVEX BANK» & 7 & 117 & 9 & 2 & 1 & 0 & 0 & 0 & 2 & 1 \\
\hline JSC «Idea Bank» & 10 & 127 & 12 & 2 & 0 & 5 & 0 & 0 & & 1 \\
\hline \multicolumn{11}{|c|}{ 3. Banks with private capital } \\
\hline JSC «FUIB» & 39 & 414 & 33 & 8 & 39 & 21 & 0 & 0 & 9 & 53 \\
\hline JSC «TASCOMBANK» & 16 & 369 & 33 & 3 & 1 & 13 & 0 & 4 & 5 & 24 \\
\hline JSC «MEGABANK» & 18 & 124 & 16 & 3 & 1 & 1 & 0 & 0 & 2 & 25 \\
\hline $\begin{array}{l}\text { JSC «BANK CREDIT } \\
\text { DNEPR» }\end{array}$ & 10 & 111 & 5 & 1 & 0 & 6 & 0 & 0 & 4 & 0 \\
\hline
\end{tabular}

Source: compiled by the author according to the data $[18,19]$. 
Table 4 shows that the largest number of information messages of the leading banks of Ukraine by categories of means of disseminating information is observed in the Online media, as the Internet is a convenient and effective communication channel and inexpensive compared to television.

In today's conditions, a growing role of the media in the communications of Ukrainian banks is observed. The number of mentions of Ukrainian banks in the media from 01.05.2020 to 31.10 .2020 has increased.

Today, in the banking sector, online media coverage prevails over offline, and with the increase in the length of the covid-19 period and the digitalization of communications, it will continue to grow. More than $90 \%$ of the media corevage of the banking sector falls on online media. In percentage terms, the largest number of mentions in the top media falls on JSC CB «PrivatBank»-13.6\% and JSC «Raiffeisen Bank Aval»-12.4\%. JSC «ALFA-BANK»-21.8\% and Monobank - $19.7 \%$ are most often mentioned in profile sources. For all banks except JSC CB «PrivatBank» and JSC «Oschadbank», a larger percentage of mentions are in the profile media. This shows the growing role of industry media in the communications of Ukrainian banks [16].

Evaluation of media efficiency of commercial banks is based on the following indicators $[16,20]$ :

- Media Visibility (MV) - an indicator of visibility in the media. The indicator is calculated on the basis of such characteristics as tonality, role of mention (main, secondary, episodic), mass media rating.

-Media Quality (MQ) - an indicator of the quality of communications. Built on the basis of such parameters as the role of mention, tonality, eventy, type and level of mass media.

-Media Favourability Index (MFI) - this is one of the quantities for measuring the effectiveness of communications, which is based on tonality. It is based on the ratio of the number of positive messages to negative ones. If positive predominates, then MFI is greater than 1 (positive messages predominate), if negative, then on the contrary - MFI is less than 1 (of negative publications more than of positive), if $\mathrm{MFI}=1$ the number of positive and negative publications is the same.

The MV and MQ indices do not depend on each other. For example, the highest MV indicator in JSC CB «PrivatBank» is 32957.2. This was influenced by the largest number of mentions in the media. But if you look at the MQ results, the best indicator in JSC «UKRSIBBANK» is 0.59 . This means that the quality of mentions in the media in him is higher than in other banks, although by the number of mentions hi significantly inferior than competing banks. The most balanced visibility in the media and quality of mentions in JSC «Raiffeisen Bank Aval». Both indicators as MV 5892.9 and MQ 0.53 are quite high compared with others in given banking institution. The highest rates of media commitment are in JSC «Raiffeisen Bank Aval»- 2.30 and JSC «OTP BANK»- 2.24. JSC «OTP BANK» received the fewest media mentions among all banks, but his MFI indicator is one of the best. The opposite example is JSC «Oschadbank», which has a high quantitative coverage, but his MFI is 0.90. When assessing the effectiveness of communications should always take into account both quantitative and qualitative parameters, because they do not always coincide in value [16].

The characteristics of the media field of banks also indicate that [21]:

- external, non-customer communications remain very important for banks, because for the successful business of banks it is necessary to form a favorable attitude towards them on the part of the state and the absence of reputational turbulence on its part. Most of the part of the messages on banks (53\%) were in the context of either their relations with the state (NBU, Ministry of Finance, government, parliament, local authorities) or relations with society (participation in social projects and initiatives); 
-the least attention media was observed in regarding messages on the promotion (marketing) by banks of products and services;

-the number of texts on financial innovations and the digital component of bank services is growing. More than $30 \%$ of the media-field, by a result 2020, are banking products and services (retail, services for large corporate business). The maximally digitalized (in the media) were JSC «ALFA-BANK» and JSC «Raiffeisen Bank Aval» (with markers of innovation concentration of $15 \%$ and $11 \%$, in accordance);

-banks' efforts to form a reputation through media-tools in 2020 do not increase (compared to previous periods). On average, 20\% of the media field of banks is their presence in the rating of influential media, due to which institutions formation the reputation of stakeholders;

-banks' efforts to formation the image of services in 2020 are not growing compared to previous periods. On average, $28 \%$ of the media field of banks is the presence of specialized media, which are a platform for the promotion of services;

-Ukrainian banks strive mainly for an impersonal model of communication with the market and the professional community. On average, only $10 \%$ of each bank's publications are accompanied by comments from managers or bank owners. JSC «BANK CREDIT DNEPR» was the bank out the most active participation of speakers in the formation of the media field (almost $50 \%$ of the bank's mentions in the media are accompanied by comments from the bank's speakers);

-according to the values of the indices of probable media loyalty to infooccasions and the possibility of probable contact of infooccasions with the media audience, the leadership is among the private banks of the project - Monobank (works on the base of JSC «UNIVERSAL BANK») (these parameters are applied to measure the resonance quality);

-among the banks that were most dynamic in formation their own media image and tried to very actively influence the content and structure of their own media field, the leadership at JSC «BANK CREDIT DNEPR» and JSC «ALFA-BANK» in value of Media Field Event Density Index (the another one tool for measuring communication quality);

-one of the many options for assessing the outcome of communications is the analysis of the traffic of banking sites. The largest of traffic, according to the results of 2020, shows of website of JSC CB «PrivatBank», the largest growth in 2020 the traffic of websites - in monobank, Pivdennyi Bank, JSC «OTP BANK» and JSC «UKRSIBBANK».

Today, Ukrainian banks pay more attention to media communications to shape their image.

Conclusions from this research and prospects for further developments in this area. At the present stage of development of Internet-communications in activities banking, it is advisable for banking institutions to use advertising, digital and creative strategies. It was found that the current trends in the development of marketing communications on the Internet also indicate the growth of Internet-communications in social networks as an important mechanism for interesting the bank customers and formation interaction with them and the development by the bank of its website, its attractive design, updating information on it.

The results of the study showed that the largest share of Internet users in Ukraine uses mobile phones or smartphones, the number of which is growing, which expands the capabilities of banks in the field of Internet-communications. It was established that the most active banks in the media space are banks with state share: JSC CB «PrivatBank», JSC «Oschadbank», JSC «Ukreximbank» and banks of foreign banking groups such as JSC «Raiffeisen Bank Aval», JSC «OTP BANK», JSC «ALFA-BANK». Among the banks with private capital is JSC «FUIB». At the same time, the largest media activity of banks in 2019 was observed in banks of foreign banking groups, and in 2019, 2021 by the number of messages in state-owned banks.

M. Demko. Development of integrated marketing Internet communications in the activity 109 of Ukrainian banks 
The analysis of the collected marketing information showed that the largest number of messages from the leading banks of Ukraine by categories of media was observed in the Internet media, as the Internet is a convenient, cheap and effective communication channel in all areas activities. The expediency of using the Internet to promote banking products is also due to the fact that recently the effectiveness of traditional channels for disseminating information about banks and their products has decreased.

Further research is aimed at analyzing foreign experience in the application of integrated marketing communications in the banking sector and its adaptation to domestic realities.

1. Malinoshevsjka K.I. (2011) Rolj integhrovanykh marketynghovykh komunikacij dlja aviakompanij [The role of integrated marketing communications for airlines]. Economics. Investments: practice and experience, no. 20 , pp. 77-80.

2. Kulyk A.S. (2016) Zasoby marketynghovykh komunikacij na suchasnomu rynku: perevaghy ta nedoliky [Means of marketing communications in the modern market: advantages and disadvantages] Proceedings of the Junistj nauky - 2016: socialjno-ekonomichni ta ghumanitarni aspekty rozvytku suspiljstva (Ukraine, Chernihiv, May 18-19, 2016), Chernighiv: Chernighivsjkyj nacionaljnyj tekhnologhichnyj universytet, pp.87-89.

3. Dubovyk T.V., Ortynsjka V.V. (2015) Upravlinnja integhrovanymy Internet-marketynghovymy komunikacijamy pidpryjemstv [Management of integrated online marketing communications enterprises] Economic problems of development of branches and types' of economic activity. Market Relations Development in Ukraine, no. 10 (173), pp. 61-65.

4. $\quad$ Kosar N.S., Panjkivsjka Ju.M., Kuzjo N.Je. (2019) Tendenciji rozvytku marketynghovoji zbutovoji ta komunikacijnoji polityky $\mathrm{v}$ umovakh aktyvnogho rozvytku informacijnykh tekhnologhij [Trends of development of marketing sales and communication policy in the conditions of active information technologies development]. Market infrastructure, no. 31, pp. 281-288. Available at: http://www.market-infr.od.ua/journals/2019/31_2019_ukr/44.pdf (accessed 01 February 2021).

5. Duchynsjka N.I., Ghuljajeva K.V. (2016) Rozvytok Internet-komunikacij v Ukrajini: osoblyvosti ta perspektyvy [Development of Internet communications in Ukraine: features and prospects]. Bulletin of Dnipropetrovsk University. Economics series, vol. 10 (2), pp. 71-77.

6. Bradulov P.O. Zasoby marketynghovykh komunikacij na osnovi Internet-marketynghu [Means of marketing communications based on Internet marketing]. Proceedings of the Naukove myslennja. KhIKh vseukrajinsjka praktychno-piznavaljna Internet-konferencija Available at: https://naukam.triada.in.ua/index.php/konferentsiji/49-dev-yatnadtsyata-vseukrajinska-praktichnopiznavalna-internet-konferentsiya/439-zasobi-marketingovikh-komunikatsij-na-osnovi-internetmarketingu (accessed 01 February 2021).

7. Zacna L. (2013) Innovacijni mozhlyvosti zastosuvannja komunikacij v Internet-marketynghu [Innovative possibilities of the use communications in Internet marketing]. Galician economic journal, no. 4(43), pp. 214-221 - (marketing technologies of enterprises in the modern scientific and technical environment).

8. Kuzjmenko A.V., Tretjak Ju.I. (2018) Vprovadzhennja Internet-marketynghu dlja prosuvannja produkciji pidpryjemstva (na prykladi TOV «Baryn») [Implementation of Internet marketing to promote the company's products (at the example Baryn LTD)]. Economy and society. Mukachevo State University, vol. 16, pp. 389-393.

9. Strateghija Internet-marketynghu dlja 2020 roku [Internet marketing strategy for 2020]. Available at: https://www.aval.ua/biznesu/blog/strategiya-internet-marketingu-dlya-2020-roku161(accessed 01 August 2020).

10. Maslova N.O., Khomenko B.A. (2016) Osoblyvosti komunikacijnoji polityky bankiv Ukrajiny [Features of communication policy of the bank of Ukraine]. Entrepreneurship and innovation, vol. 2, pp. 108-117.

11. Kocj O.A., Bondarenko L.P. (2017) Osoblyvosti roboty ukrajinsjkykh bankiv u socialjnykh merezhakh [Specifics of ukrainian banks activity in social networks]. Actual Problems of Economics. 
Scientific economic journal, no. 3(189), pp. 316-324.

12. Veselova M.Ju. (2014) Novi tendenciji marketynghovoji dijaljnosti komercijnykh bankiv: zarubizhnyj dosvid [New tendencies of the marketing activity of commercial banks: foreign experience]. Sustainable development of economy. International scientific and production journal, no. 3, pp. 217222.

13. Kosar N.S., Kuzjo N.Je. (2018) Naprjamy vtilennja innovacij u marketynghovu dijaljnistj komercijnykh bankiv ukrajiny u suchasnykh umovakh [Directions of innovations implementation in the ukrainian commercial banks marketing activities in modern conditions]. Economics and law, no. 1 (49), pp. 143-150.

14. Ghirchenko T.D., Koscmann R. (2016) Vprovadzhennja ta rozvytok cyfrovogho marketynghu u suchasnomu bankivsjkomu biznesi [Implementation and development of digital marketing in modern banking business]. Wspótpraca europejska. European cooperation, vol. 12(19), pp. 68-85. Available at: european-cooperation.eu > index.php >2016. № 12(19) (accessed 01 February 2021).

15. Typy dostupu «reghuljarnykh» Internet-korystuvachiv III kvartal 2019. [Types of access of «regular» Internet users III quarter of 2019]. Internet-audience research. Internet Association of Ukraine. $\quad$ Available

https://inau.ua/sites/default/files/file/1910/dani_ustanovchyh_doslidzhen_iii_kvartal_2019_roku.pdf (accessed 01 February 2021).

16. Doslidzhennja: Mediapole bankivsjkoji sfery Ukrajiny protjaghom travnja-zhovtnja 2020 roku [Research: Media-field of the banking sector of Ukraine during May-October 2020]. INVESTGAZETA. Available at: https://investgazeta.ua/blogs/doslidzhennya-mediapolya-bankivskoji-sferi-ukrajini-zaperiod-z-travnya-po-zhovten-2020-roku (accessed 01 February 2021).

17. Solodsjkykh A.S., Vasyljjeva T.A. (2014) Media-analiz rezuljtativ dijaljnosti bankiv Ukrajiny u rozrizi marketynghovykh komunikacij [Media analysis of results of activity of ukrainian banks in terms of marketing communications]. Young scientist, no. 6(2), pp. 42-44. Available at: http://www.irbis-nbuv.gov.ua/cgi-

bin/irbis_nbuv/cgiirbis_64.exe?I21DBN=LINK\&P21DBN=UJRN\&Z21ID=\&S21REF=10\&S21CNR $=20 \& S 21 S T N=1 \& S 21 F M T=A S P \_m e t a \& C 21 \mathrm{COM}=S \& 2 \_S 21 \mathrm{P} 03=F I L A=\& 2 \_S 21 \mathrm{STR}=$ molv_2014 6(2)__13 (accessed 01 February 2021).

18. Medijnyj rejtyngh bankiv [Media rating of banks]. Independent Association of Banks of Ukraine. Available at: https://nabu.ua/ua/media-aktivnist.html (accessed 01 February 2021).

19. Semantrum. Available at: https://promo.semantrum.net/uk/vedia-rating-banks-ukraine-2017/ (accessed 01 February 2021).

20. Jak ocinyty media-efektyvnistj: 3 gholovni indeksy dlja PR-fakhivciv [How to evaluate media efficiency: 3 main indices for PR professionals]. LOOQME. Available at: https://looqme.io/uk/blog/yak-ociniti-media-efektivnist-3-golovni-indeksi-dlya-pr-fakhivciv (accessed 01 February 2021).

21. 2020: jak ukrajinsjki banky za dopomoghoju ZMI formuvaly svij imidzh [2020: how Ukrainian banks formed their image with the help of the media]. FinClub. Available at: https://finclub.net/ua/reviews-ua/2020-iak-ukrainski-banky-za-dopomohoiu-zmi-formuvalysvii-imidzh.html (accessed 01 February 2021).

Демко Мар'яна Ярославівна, аспірантка кафедри маркетингу економічного факультету Львівського національного університету імені Івана Франка (Львів, Украйна).

\section{украӥнських банків. \\ Розвиток інтегрованих маркетингових Інтернет-комунікацій в діяльності \\ У сучасних умовах стрімко відбувається розвиток мережі Інтернет. Маркетингові} комунікаиії в мережі Інтернет є одним з основних елементів Інтернет-маркетингу банківських установ та важливим елементом встановлення відносин з иільовими аудиторіями та управління ними, інформування клієнтів, підвищення іміджу банку. Визначено, що мережа Інтернет сьогодні охоплює інформаційну, комунікаџійну та логістичну сфери маркетингових комунікацій банків. У роботі виокремлено сфери інтегрованих маркетингових Інтернет-

M. Demko. Development of integrated marketing Internet communications in the activity 111 of Ukrainian banks 
комунікаиій в діяльності банків та їх головні елементи, подано їх характеристику. На сучасному етапі розвитку Інтернет-комунікацій у банківській діяльності доиільним є застосування банківськими установами рекламної, цииррової і креативної стратегії. 3'ясовано, що сучасні тенденції розвитку маркетингових комунікацій в Інтернеті свідчать також про зростання Інтернет-комунікацій в сочіальних мережах як важливого механізму зачікавлення банком клієнтів та формування взаємодї з ними і розроблення банком свого веб-сайту, його привабливого оформлення, оновлення інформаиії на ньому. Результати дослідження показали, що найбільша частка Інтернет-користувачів в Украйні застосовує мобільні телефони або смартфони, кількість користувачів яких зростає, що розширює можливості банків у сфері Інтернет-комунікацій. При изьому встановлено, що найбільш активні банки в медійному просторі - ие банки з державною часткою: АТ КБ «Приватбанк», АТ «Ощадбанк», АТ «Укрексімбанк» $і$ банки іноземних банківських груп такі як АТ «Райффайзен Банк Аваль», АT «ОТП БАНК», АТ «АЛЬФА-БАНК». Серед банків з приватним капіталом можна виокремити АТ «ПУМБ». При иьому найбільша медіа-активність банків у 2019 р. спостерігалася у банків іноземних банківських груп, а в 2019 р., 2021 р. - за кількістю повідомлень у державних банків. Аналіз зібраної маркетингової інформації показав, щуо найбільша кількість повідомлень провідних банків Украӥни за категоріями засобів поширення інформаиії спостерігалася в Інтернет-3МI, оскільки Інтернет є зручним, дешевим та ефективним комунікачійним каналом у всіх сферах діяльності. Доцільність застосування Інтернету для просування банківських продуктів обумовлена також тим фактом, що останнім часом зменшується ефективність традииійних каналів поширення інформаиї̈ про банки та їх продукти.

Ключові слова: інтегровані Інтернет-маркетингові комунікації, банки, Інтернетмаркетинг, медіа-активність банків, засоби поширення інформації.

Received to the editor 17 February, 2021. 